\title{
The Effects of Whole Body Vibration Training on Some Biochemical Values in Terms of Osteoporosis Risk in Premenopausal Women
}

\author{
Nurcan Demirel ${ }^{1}$, Fatih Kaya ${ }^{2}$, Salih Pınar ${ }^{3}$ \\ ${ }^{1}$ Atatürk University, School of Physical Education and Sports -Erzurum, Turkey \\ ${ }^{2}$ Erzincan University, Faculty of Education, Department of Physical Education and Sports, Turkey \\ ${ }^{3}$ Marmara University, School of Physical Education and Sports -İstanbul, Turkey \\ Correspondence: Nurcan Demirel, Atatürk University, School of Physical Education and Sports -Erzurum, Turkey.
}

Received: March 22, 2018

doi:10.11114/jets.v6i4a.3192
Accepted: April 7, $2018 \quad$ Online Published: April 9, 2018

URL: https://doi.org/10.11114/jets.v6i4a.3192

\begin{abstract}
The main purpose of the present study is to comparatively examine the effects of Whole body vibration (WBV) trainings on some biochemical bone-turnover markers (Beta-CTx, Osteocalcin) in terms of osteoporosis. Twenty-four sedentary women (mean age $=37.12 \pm 1.84$ years) participated in the study. The participants were randomly divided to 3 groups: whole body vibration exercise group (WBV, $n=8)$, classical resistance exercise group $(\mathrm{CR}, \mathrm{n}=8)$, and control group $(\mathrm{CO}$, $\mathrm{n}=8$ ). Vibration trainings and classical resistance trainings were applied in similar exercise models for major muscle groups three days a week for eight weeks, not on consecutive days but in the same contexts. Of biochemical values, Beta-CTx and Osteocalcin were analysed by using Cobas e 411 ECLIA (Electro Chem. Luminance Immune Assay) method before and after the eight-week exercise period. For intra-group comparisons paired-samples t-test, for inter-group comparisons one way ANOVA, and for multi-comparisons Tukey test were used. While a statistically significant difference was found between pretest posttest of Beta-CTx and Osteocalcin values of $\mathrm{CR}(\mathrm{p}<.05)$, there was not a significant difference in WBV and CO groups ( $p>.05$ ). A statistically significant difference was found between the groups in terms of pretest posttest biochemical value changes (Beta-CTx, Osteocalsin) of the participants ( $\mathrm{p}<.05$ ). As a result, eight-week WBV training in premenopausal women can be considered as safe in terms of biochemical values' (Beta-CTx, Osteocalcin) remaining unchanged. On the other hand, CR training made significant changes on the values in question. Whether this change is an acute effect or not has become a raising question. This case can be studied in premenopausal women in further research.
\end{abstract}

Keywords: pre-menopause, vibration exercise, Beta-CTx, osteocalcin

\section{Introduction}

A systemic disease, osteoporosis, which is characterised by low bone mass, is an important public health problem (Uçan et al. 2007). Dynamic stress applied on bone causes an increase in bone mass as a biological response. This case was clearly seen in women who did regular sport from young ages. When these women went through menopause, their total bone mass was found $40 \%$ higher than of those who lived a sedentary lifestyle. Physical activity maintains the structural competence of bone mass (Aydil, 2005). Exercise with extra load (strength training) stimulates osteoblastic activity, and insensibly decreases the speed of the osteoblastic activity and resorption (Bosco et al. 1999). Exercise has a protective effect on skeleton against osteoporosis (Biering-Sorensen et al. 1988). Fast bone loss caused by estrogen deficiency in premenopausal women can slow down by exercise (Kutsal, 2001; Kutsal, 2001).

\section{Relevant Literature}

Bone formation and destruction balance each other by occurring in cycle. At young ages, the balance in regeneration is in favour of formation. Consequently, due to the redundancy in formation, bone tissue reaches the top level in trabecular bones (i.e. vertebras) at the age of 25-30 and in cortical bones (i.e. femur) at the age of 35-40. After that, continuous bone loss begins in accordance with the increase in destruction. The mean annual bone loss is approximately $0.25-1 \%$. However, this rate increases to \%2-3 in pre-menopausal women, and lasts in postmenopausal period for 5-10 years. Premenoupausal period varies accroding to individuals and societies; it begins at the ages of 35-40 and lasts till the ages of 55-60 (Saraçoğlu, 1998). It is a successive formation, resorption, mineralization cycle, which is called as "turnover". It 
ensures the bone tissue stamina. To evaluate this bone cycle, some biochemical indicators are used. To determine bone loss velocity, Osteocalcin and CTx are mostly used as bone cycle indicators. One of the markers of bone turnover speed in blood is Osteocalcin, and of the bone destruction is CTx (Raisz et al. 2000; Koç et al 2004). The aim of this study is to comparatively examine the effects of Whole body vibration (WBV) trainings on some biochemical values (Beta-CTx, Osteocalcin).

\section{Methods}

\subsection{Participants}

24 sedentary women, who were determined as being in premenopausal period according to their hormonal values, participated in the study (mean age $=37.12 \pm 1.84$ years). Their hormone levels and bone density were tested. The participants were randomly divided into three groups: whole body vibration exercise group (WBV, $\mathrm{n}=8$ ), classical resistance exercise group $(\mathrm{CR}, \mathrm{n}=8)$, and control group $(\mathrm{CO}, \mathrm{n}=8)$.

\subsection{Training Procedure}

Vibration trainings (with Power Plate-Pro5) and classical resistance trainings (with Gymstick) were applied in the same and similar exercise models for major muscle groups three days a week for eight weeks, not on consecutive days but in the same contexts. In both training programmes, the duration and intensity were increased at the end of the $4^{\text {th }}$ week in accordance with load principles (principle is individual basic incremantaly). Of biochemical values, Beta-CTx and Osteocalcin were analysed before and after the eight-week exercise period. For the analysis, Cobas e 411 ECLIA (Electro Chem. Luminance Immune Assay) method was used.

\subsection{Data Analysis}

For intra-group comparisons paired-samples t-test, for inter-group comparisons one way ANOVA, and for multi-comparisons Tukey test were used. The significance level was determined as $\mathrm{p} \leq 0.05$.

\section{Findings}
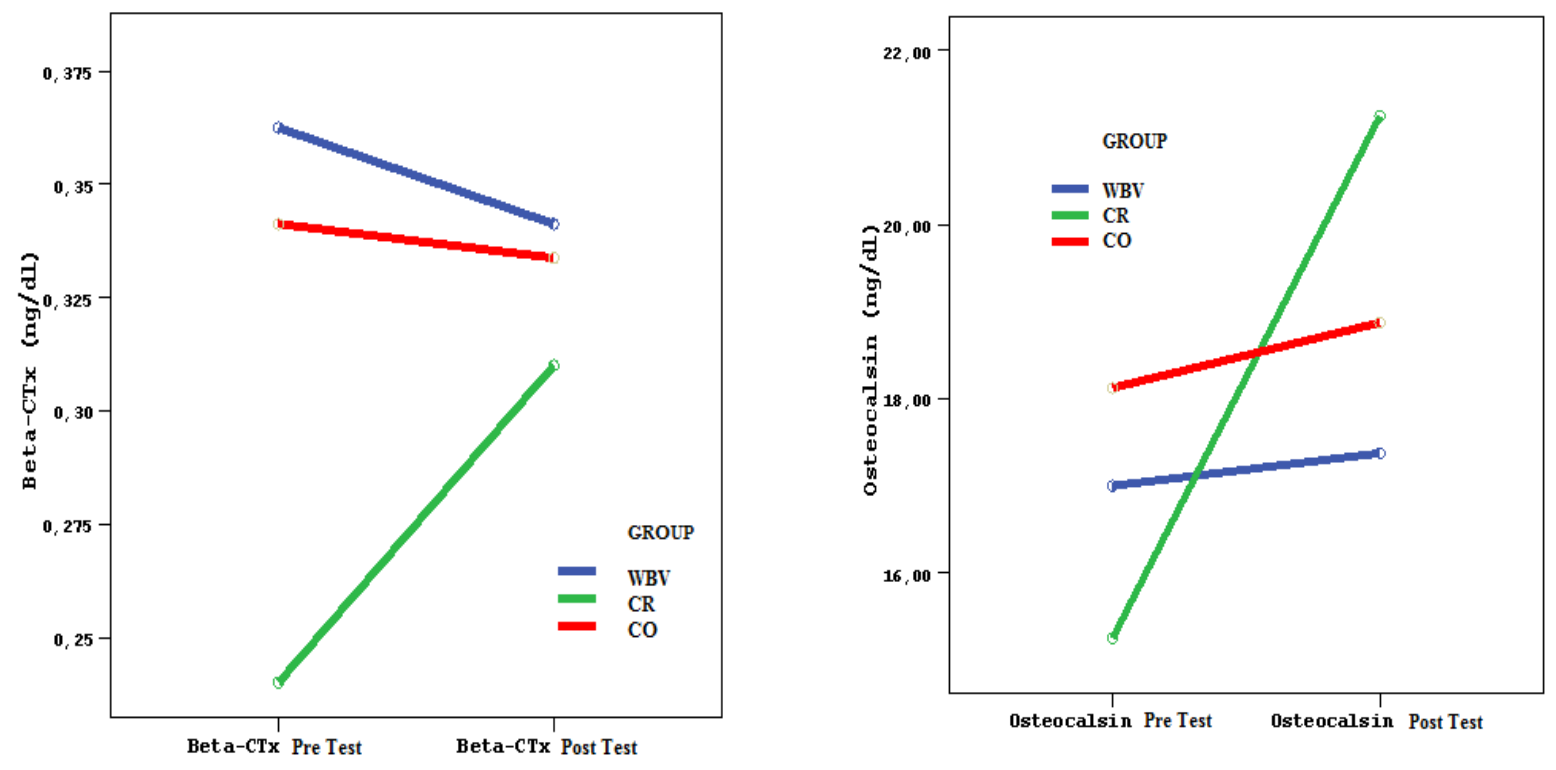

Figure 1. Of the biochemical markers of bone turnover, Beta-CTx and Osteocalcin values

As a result of the statistical analysis, there was not a statistically significant difference between the pretest-postest values for Beta-CTx and Osteocalcin of WBV group $[(\mathrm{t}(7)=.713, \mathrm{p}=.499), \mathrm{t}(7)=-.375, \mathrm{p}=.718$, respectively, Table 1].

There was a statistically significant difference between the pretest-postest values for Beta-CTx and Osteocalcin of CR group $[\mathrm{t}(7)=-3.632 . \mathrm{p}=.008 . \mathrm{t}(7)=-5.084 . \mathrm{p}=.00,1$ respectively]. Biochemical Beta-CTx and Osteocalcin scores of CR group significantly increased from pretest to posttest.

There was no statistically significant difference between the pretest-postest values for Beta-CTx and Osteocalcin of CO group. $[\mathrm{t}(7)=.284, \mathrm{p}=.785, \mathrm{t}(7)=-1.821, \mathrm{p}=.111$, respectively]. 
Table 1. Changes in biochemical values of whole body vibration exercise (WBV)

\begin{tabular}{llccccc}
\hline & & Mean $(\mathrm{SS})$ & t & sd & p & \% change \\
\hline \multirow{2}{*}{ Beta-CTx (ng/mL) } & Pretest & $.36(.09)$ & .713 & 7 & .499 & -5.56 \\
& Posttest & $.34(.09)$ & & & & \\
Osteocalcin (ng/mL) & Pretest & $17.00(3.54)$ & & & \\
& Posttest & $17.37(1.92)$ & & 7 & .718 & 2.18 \\
\hline
\end{tabular}

p>.05

Table 2. Changes in biochemical values of classical resistance (CR)

\begin{tabular}{|c|c|c|c|c|c|c|}
\hline & & Mean (SS) & $\mathbf{t}$ & sd & $\mathbf{p}$ & $\%$ change \\
\hline \multirow{2}{*}{ Beta-CTx (ng/mL) } & Pretest & $.24(.08)$ & \multirow{2}{*}{$-3.632 * *$} & \multirow{2}{*}{7} & \multirow{2}{*}{.008} & \multirow{2}{*}{29.16} \\
\hline & Posttest & $.31(.12)$ & & & & \\
\hline \multirow{2}{*}{ Osteocalcin (ng/mL) } & Pretest & $15.25(4.20)$ & \multirow{2}{*}{$-5.084 * *$} & \multirow{2}{*}{7} & \multirow{2}{*}{.001} & \multirow{2}{*}{39.34} \\
\hline & Posttest & $21.25(6.06)$ & & & & \\
\hline
\end{tabular}

$* * \mathrm{p}<.01$.

Table 3. Changes in biochemical values of control (CO)

\begin{tabular}{|c|c|c|c|c|c|c|}
\hline & & Ort (SS) & $\mathbf{t}$ & sd & $\mathbf{p}$ & $\%$ change \\
\hline \multirow{2}{*}{ Beta-CTx (ng/mL) } & Pretest & $.34(.11)$ & \multirow{2}{*}{.284} & \multirow{2}{*}{7} & \multirow{2}{*}{.785} & \multirow{2}{*}{-2.94} \\
\hline & Posttest & $.33(.08)$ & & & & \\
\hline \multirow{2}{*}{ Osteocalcin (ng/mL) } & Pretest & $18.12(3.60)$ & \multirow{2}{*}{-1.821} & \multirow{2}{*}{7} & \multirow{2}{*}{.111} & \multirow{2}{*}{4.13} \\
\hline & Posttest & $18.87(3.94)$ & & & & \\
\hline
\end{tabular}

p>.05

According to the ANOVA results, a statistically significant difference was found between the groups in terms of pretest-posttest Beta-CTx and Osteocalcin changes of the participants $[F(2.21)=3.709 ; p=.042 . F(2.21)=11.589, p=.000$, respectively].

According to the Post- Hoc analysis results, a statistically significant difference was found between WBV and CR groups in terms of Beta-CTx scores ( $\mathrm{p}<.05)$. The mean change in Beta-CTx scores of CR group ( $\overline{\mathrm{x}}=.07)$ was higher than of WBV group $(\overline{\mathrm{x}}=.02)$. In terms of Osteocalcin scores, there was a significant difference between WBV group and CR group, and between $C R$ group and $C O$ group $(p<.05)$. The mean change in Osteocalcin scores of $C R$ group $(\bar{x}=6.00)$ was higher than of CO group $(\overline{\mathrm{x}}=.75)$ and of WBV group $(\overline{\mathrm{x}}=.37)$.

\section{Results and Discussion}

Reviewing literature, it can be seen that vibration was used as a treatment and healing method in medicine and physiotherapy. When previous studies are reviewed, it can be observed that there are a great number of studies reporting that WBV training are effective on reducing muscle and bone pain, on increasing sense of strength, and also on decreasing bone mineral loss (Guieu et al 1990; Lundeberg et al 1988; Lundeberg et al 1984; Caferelli \& Kostka 1981; Caferelli \& Layton-Wood 1986; Flieger et al 1998; Kin- İşler, 2007).

In a previous study, it was aimed to identify the effects of vibration on bone, physical performance and body balance and so to find new approaches in order to prevent falling down and osteoporotic breaks. Vibration exercise also increases muscle strength and neuromuscular coordination, which in turn reduces the risk of osteoporosis. Whole body vibration exercise in postmenopausal osteoporosis. As a result of the study, it was asserted that the training was safe and the vibration workout was successful. However, there was no effect on bone density, structure and strength in skeleton part. There were no changes in the serum bone regeneration markers. This result is consistent with the findings of the present study (Weber-Rajek et al 2015; Torvinen, 2003).

As a result, the eight-week WBV training for premenopausal women can be considered as safe in terms of biochemical bone turnover markers' (Beta-CTx, Osteocalcin) remaining unchanged. Besides this, CR training made significant changes on the values in question. Whether this change is an acute effect or not is a raising question. This case can be studied in premenopausal women in further research. 


\section{References}

Aydil, S. (2005). Osteoporozda Egzersiz Programının Solunum Fonksiyonlarına ve Yaşam Kalitesine Etkisi., İstanbul 70.Yll Fizik Tedavi ve Rehabilitasyon Eğitim v eAraştırma Hastanesi, Uzmanlık Tezi, İstanbul.

Biering-Sorensen, F., Bohr, H., \& Schaadt, O. (1988). Bone Mineral Content of the Lumbar Spine and Lower Extremities Years After Spinal Cord Lesion. Paraplegia; 26, 293-301. https://doi.org/10.1038/sc.1988.44

Bosco, C., Cardinale, M., Tsarpela, O., \& Locatelli, E. (1999). New Trends in Training Science: The Use of Vibrations for Enhancing Performance. New Studies in Athletics, 14(4), 55-62.

Cafarelli, E., \& Kostka, C. E. (1981). Effect of Vibration on Static Force Sensation in Man. Experimental neurology, 74(2), 331-340. https://doi.org/10.1016/0014-4886(81)90173-4

Cafarelli, E., \& Layton-Wood, J. (1986). Effect of Vibration on Force Sensation in Fatigued Muscle. Medicine and Science in Sports and Exercise, 18(5), 516-521. https://doi.org/10.1249/00005768-198610000-00004

Flieger, J., Karachalios, T., Khaldi, L., Raptou, P., \& Lyritis, G. (1998). Mechanical Stimulation in the Form of Vibration Prevents Postmenopausal Bone Loss in Ovariectomized Rats. Calcified Tissue International, 63(6), 510-514. https://doi.org/10.1007/s002239900566

Guieu, R., Tardy-Gervet, M. F., Blin, O., \& Pouget, J. (1990). Pain Relief Achieved by Transcutaneous Electrical Nerve Stimulation and/or Vibratory Stimulation in a Case of Painful Legs and Moving Toes. Pain, 42(1), 43-48. https://doi.org/10.1016/0304-3959(90)91090-6

Kin, İ. A. (2007). Effects of Vibration on Performance, Spor Bilimleri Dergisi Hacettepe Journal of Sport Sciences, 18(1), 42-56.

Koç, H., Sekban, H., Bahadır, C., Gürer, N., Atalay, S., \& Önder, C. B. (2004). The Effects of Risedronate Therapy Combined With Vitamin D and Calcium on Biochemical Markers of Bone Turnover and Bone Mineral Density in Postmenopausal Osteoporosis., Osteoporoz Dünyasindan, 10(4), 161-164.

Kutsal, G. Y. (2001). Modern Tıp Seminerleri 19:Osteoporoz, Güneş Kitabevi, Ankara.

Kutsal, G. Y. (2001). Osteoporoz, Roche, Sayfa; 24.istanbul.

Lundeberg, T., Abrahamson, P., Bondesson, L., \& Ahker, E. (1988). Effect of Vibratory Stimulation on Experimental and Clinical Pain. Scandinavian Journal of Rehabilitation Medicine Scan, 20, 149-159.

Lundeberg, T., Nordemar, R., \& Ottoson, D. (1984). Pain alleviation by vibratory stimulation. Pain, 20, 25-44. https://doi.org/10.1016/0304-3959(84)90808-X

Raisz, L., Smith, J.A., Trahiotis, M., Fall, P., Shoukri, K., Digennaro, J., \& Sacco-Gibson, N. (2000). Short-Term Risedronate Treatment in Postmenopausal Women, Effects on Biochemical Markers of Bone Turnover. Osteoporosis Int., 11(7), 615-620. https://doi.org/10.1007/s001980070083

Saraçoğlu, F. (1998). MENOPAUSE and HORMONE REPLACEMENT THERAPY/Effects on Osteoporosis, Cardiovascular Diseases, Carbonhydrate Metabolism and Cancer Development., Geriatri (Turkish Journal of Geriatrics). 1(2), 76-88.

Torvinen, S. (2003). Effect of Whole Body Vibration on Muscular Performance, Balance, and Bone. Academic dissertation, University of Tampere, Finland.

Uçan, Ö., Taşcı, S., \& Ovayolu, N. (2007). Osteoporozda Risk Faktörleri ve Korunmanın Önemi., Fırat Sağllk Hizmetleri Dergisi, 2, 6.

Weber-Rajek, M., Mieszkowski, J., Niespodziński, B., \& Ciechanowska, K. (2015). Whole body Vibration Exercise in Postmenopausal Osteoporosis. PMC-Prz Menopauzalny, 14(1), 41-47. https://doi.org/10.5114/pm.2015.48679

\section{Copyrights}

Copyright for this article is retained by the author(s), with first publication rights granted to the journal.

This is an open-access article distributed under the terms and conditions of the Creative Commons Attribution license which permits unrestricted use, distribution, and reproduction in any medium, provided the original work is properly cited. 